\title{
Immobilization of trypsin on spent grains for whey protein hydrolysis
}

\author{
C. Rocha ${ }^{a, b, *}$, M.P. Gonçalves ${ }^{b}$, J.A. Teixeira ${ }^{a}$ \\ a Institute for Biotechnology and Bioengineering (IBB), Centre of Biological Engineering, Universidade do Minho, Campus de Gualtar, 4710-057 Braga, Portugal \\ ${ }^{\mathrm{b}}$ REQUIMTE, Departamento de Engenharia Química, Faculdade de Engenharia, Universidade do Porto, Rua Dr. Roberto Frias, $4200-465$ Porto, Portugal
}

\section{A R T I C L E I N F O}

\section{Article history:}

Received 29 April 2010

Received in revised form

30 September 2010

Accepted 1 October 2010

\section{Keywords:}

Spent grains

Immobilization

Trypsin

Whey protein

Hydrolysis

\begin{abstract}
A B S T R A C T
The aims of this work were to establish an efficient protocol for trypsin immobilization on spent grains and to assess the influence of the chosen protocol on whey protein hydrolysis. Trypsin was immobilized onto spent grain or modified spent grain, through adsorption and covalent attachment. The efficiency of immobilization and operation and storage stabilities of free and immobilized enzyme on the supports were studied. The enzyme activity, kinetic parameters and the peptide profile of the protein hydrolysates from free and immobilized enzyme were also analysed.

The best activity retention was achieved with the immobilization on spent grains through multipoint covalent attachment using glycidol. This carrier showed also very good storage and operational stability (above 90\%). Trypsin immobilized on spent grains showed significant activity towards whey proteins. The immobilized enzyme was slightly more stable than the free enzyme at temperatures between $50{ }^{\circ} \mathrm{C}$ and $60^{\circ} \mathrm{C}$ allowing its use at a broader range of temperatures. The peptides formed with free enzyme and enzyme immobilized on spent grains were generally similar. However, significant differences existed in the amount of native proteins in the hydrolysates and in the relative amount of smaller peptides.
\end{abstract}

(c) 2010 Elsevier Ltd. All rights reserved.

\section{Introduction}

Whey proteins are widely used in food formulation due to their nutritional and functional properties [1,2]. From a dietary point of view, enzymatic hydrolysis of whey proteins is interesting, e.g., to reduce allergenicity or to produce bioactive peptides. Many known bioactive peptides have been released by pancreatic enzymes - preferably trypsin - as well as other enzymes including Alcalase ${ }^{\circledR}$ and pepsin (e.g., [3-5]). Hydrolysis of whey proteins with pancreatic enzymes or with Alcalase ${ }^{\circledR}$ has also been used to improve functional properties of foods such as modification of the gelation behaviour, improvement of thermal stability, change solubility, improvement of foamability and foam stability, improvement of water and fat holding capacities, improvement of emulsifying capacity and/or tailor the functionality of the protein to meet specific needs [6-9]. The desired degree of hydrolysis and the adequate source of protein depend on the desired functionality and on type of product in which they will be incorporated.

The accurate control of the degree of hydrolysis and, thus, of the hydrolysates' properties is only possible if the hydrolysis can be stopped at the exact moment and with a non-aggressive method. For instance, when a free enzyme is utilized for catalysis, the use

\footnotetext{
* Corresponding author at: REQUIMTE, Departamento de Engenharia Química, Faculdade de Engenharia, Universidade do Porto, Rua Dr. Roberto Frias, 4200-465 Porto, Portugal. Tel.: +351 22508 1400; fax: +351225081449.

E-mail addresses: cmrocha@fe.up.pt, crocha@deb.uminho.pt (C. Rocha).
}

of heat to inactivate the enzyme results in the denaturation of protein molecules causing the loss of tertiary and quaternary structures that are essential for protein functionality [8]. If the enzyme is immobilized on a carrier which is easily removable from the reaction medium this can be almost instantaneously done without further interferences. Depending on the properties of the carrier, simple sedimentation, filtering or centrifuging can be enough. If magnetic properties can be added to the carrier (e.g., ferromagnetic Dacron [10]) it can be easily removed by applying a magnetic field. However, differences in the hydrolysates may arise from the use of an immobilized enzyme instead of the free enzyme [11,12]. In fact, immobilization can change, e.g., the accessibility of the enzyme to the substrate or even the affinity of the enzyme towards a specific substrate.

Several authors have been using immobilized enzymes to hydrolyse proteins. Chen et al. [3] immobilized trypsin on succinamidopropyl controlled-pore glass beads and used it to hydrolyse $\beta$-lactoglobulin ( $\beta$ - $\mathrm{Lg}$ ) with the aim of improving its gelling properties. Park et al. [13] used the same enzyme and carrier to hydrolyse casein. Trypsin immobilized on succinamidopropyl Celite was used to hydrolyse whey proteins [8]. Paramagnetic porous glass beads were used to hydrolyse fetuin with immobilized trypsin [14], while Pedroche et al. [15] used agarose gel activated with glycidol to immobilize trypsin, $\alpha$-chymotrypsin and carboxypeptidase A and to hydrolyse casein.

Although the immobilization of enzymes on solid carriers can offer several advantages over free enzymes, low mass transfer efficiency of the substrate, operational instability of the immobilized 
enzymes and, sometimes, high cost of the carrier have limited its application to the hydrolysis of proteins [16]. Besides, a biocatalyst that works well in the hydrolysis of a protein may have a poor performance in the hydrolysis of a different protein (e.g., [16,17]).

Spent grain is the major brewing by-product. It contains about 17-25\% cellulose, $21-28 \%$ non-cellulosic polysaccharides, $12-28 \%$ lignin, $15-24 \%$ protein and less than $11 \%$ lipid [18]. Spent grains are mainly used in animal feeding or landfill, but its composition, availability and low cost makes them attractive as a source of valueadded products. It has been considered for a number of applications such as human nutrition, due to its high content in proteins and fibers ( 20 and $70 \%$, respectively) and energy production $[18,19]$. Its high content in cellulose makes it an interesting carrier for enzyme immobilization because, besides having the necessary characteristics (e.g., stability, rigidity, low mass transfer limitations), they are cheap and food grade [20].

Glyoxyl or glutaraldehyde activated supports have proven to be quite efficient in increasing the tertiary enzyme stability via multipoint covalent attachment [21]. Immobilization on glyoxyl-carriers occurs at alkaline $\mathrm{pH}$, via the richest area in lysines on the proteins surface. Although immobilization of proteins at neutral $\mathrm{pH}$ values is possible, the low reactivity of the lysine at neutral $\mathrm{pH}$ hardly permits very intense multipoint covalent attachment under these conditions. To increase the multipoint covalent attachment after the first immobilization, and thus probably increase immobilized enzyme stability, it is necessary to increase the $\mathrm{pH}$ value [22]. The main advantage of this protocol is the high stability that is usually achieved [22]. Trypsin immobilized in glyoxyl-agarose, e.g., resulted in an enzyme 4700 more stable than the free enzyme [23]. To enhance the activity retention of enzyme molecules attached to the support, the glyoxyl-carrier may be aminated with ethylenediamine and activated with glutaraldehyde, allowing immobilization to occur at milder values of $\mathrm{pH}$.

The aims of this work were to efficiently immobilize trypsin onto spent grain and to assess the influence of the immobilization procedure on the whey protein hydrolysis with immobilized trypsin. The efficiency of immobilization and operation and storage stabilities of free and immobilized enzyme on the supports were studied. The enzyme activity, kinetic parameters and the peptide profile of the protein hydrolysates from free and immobilized enzyme were also analysed.

\section{Materials and methods}

All chemicals used were of analytical grade and supplied by Sigma, Co. (St. Louis, MO, USA). Trypsin from porcine pancreas with an activity of $1800 \mathrm{~N}-\alpha$-benzoylL-arginine ethyl ester (BAEE) units/mg and trypsin from bovine pancreas with an activity of 11,000 BAEE units/mg and a chymotryptic activity lower than $0.2 \%$ were also obtained from Sigma Chemical, Co. One BAEE unit will produce a $\triangle \mathrm{A} 253$ of 0.001 per min at $\mathrm{pH} 7.6$ at $25^{\circ} \mathrm{C}$ using BAEE as substrate, in a reaction volume of $3.2 \mathrm{~mL}$ and $1 \mathrm{~cm}$ light path. Spent grains were kindly supplied by UNICER S. A., Porto, Portugal.

Whey protein isolate (WPI) powder (Lacprodan DI-9212, batch R320215) was kindly supplied by Arla Foods Ingredients (Viby, Denmark). According to the suppliers, the WPI protein content was $91 \%$ dry basis, the moisture was $5.5 \%$ in maximum, the ash content was $3 \%$ and the ion content was: sodium, $<0.1 \%$, phosphorus, $0.2 \%$, chloride, $2.2 \%$, potassium, $<0.1 \%$ and calcium, $<0.1 \%$.

Solvents for HPLC were filtered through $0.22 \mu \mathrm{m}$ filters and degassed under vacuum for at least $15 \mathrm{~min}$ before use.

Purified bovine standards of $\beta$-Lg and $\alpha$-lactalbumin ( $\alpha$-La) were supplied by Sigma and dissolved in ultra purified water.

\subsection{Supports}

Spent grains were prepared as described by Brányik et al. [20]. Dry spent grains $(100 \mathrm{~g})$ were mixed in $1500 \mathrm{~mL}$ of $3 \%(\mathrm{v} / \mathrm{v}) \mathrm{HCl}$ solution at $60^{\circ} \mathrm{C}$ for $2.5 \mathrm{~h}$ in order to hydrolyse the residual starchy endosperm and embryo of the barley kernel present in the spent grains. The mixture was cooled, washed with water. The remaining solids were partially delignified by shaking $(120 \mathrm{rpm})$ in $500 \mathrm{~mL}$ of $2 \%(\mathrm{w} / \mathrm{v}) \mathrm{NaOH}$ solution at $30^{\circ} \mathrm{C}$ for $24 \mathrm{~h}$. After being several times washed with water until neutral $\mathrm{pH}$ and dried, the carrier ( $\mathrm{ca} .10 \mathrm{~g}$ ) was ready to be used.
Spent grains were activated using glycidol (2,3-epoxy-1-propanol) with subsequent oxidation with periodate as described by Guisan [24]. The carrier was then washed with distilled water and stored at $4{ }^{\circ} \mathrm{C}$. Part of the glyoxyl-spent grains was further activated with $1 \mathrm{M}$ ethylenediamine at $\mathrm{pH} 10.05$ for $2 \mathrm{~h}$ to amine-spent grains. Sodium borohydride was added to reduce reversible Schiff bases into stable amines and the carrier was gently stirred for $2 \mathrm{~h}$ more. The carrier was then washed consecutively with $\mathrm{pH} 4$ sodium acetate buffer (to destroy $\mathrm{NaBH}_{4}$ ), with $\mathrm{pH} 9$ sodium borate (to reduce electrostatic interactions) and with water [21].

\subsection{Trypsin immobilization}

Adhesion to the carriers was tested without chemical modification of the carrier surface (by physical adsorption) and with activation using glycidol (alone or with further modification to amine-spent-grain). All immobilization tests were performed at least in triplicate. For each carrier, trypsin was incubated with the carrier and appropriate buffer overnight at $4{ }^{\circ} \mathrm{C}$. The standard conditions used were as follows: $20 \mathrm{mg}$ of trypsin from porcine pancreas and $40 \mathrm{mg}$ of carrier in $2 \mathrm{~mL}$ of buffer. For simple adsorption tests, immobilization was made at $\mathrm{pH} 8$ with $0.05 \mathrm{M}$ Tris buffer. For glyoxyl-spent grain trypsin was incubated in $0.05 \mathrm{M}$ carbonate buffer $\mathrm{pH} 10$. A final step with sodium borohydride $\left(1 \mathrm{mg} \mathrm{mL}^{-1}\right)$ was performed to reduce Schiff bases into stable amines and transform the residual aldehyde groups in the support into inert hydroxyl-groups [22]. For amine-spent-grains, they were previously activated with $1 \%$ glutaraldehyde $(\mathrm{w} / \mathrm{v})$ for $2 \mathrm{~h}$ in $0.05 \mathrm{M} \mathrm{pH} 7$ phosphate buffer; trypsin was then immobilized also with $0.05 \mathrm{M}$ phosphate buffer, pH 7.0 Benzamidine ( $3 \mathrm{mM}$ as final concentration) was also tested in covalent binding as a reversible trypsin inhibitor to prevent auto-proteolysis that could promote enzyme inactivation.

In the case of whey protein hydrolysis, the more active form of trypsin with no chymotryptic activity was used. Thus, trypsin from bovine pancreas ( $30 \mathrm{mg}$ ) was incubated with $200 \mathrm{mg}$ of glyoxyl-spent grain and $5 \mathrm{~mL}$ of carbonate buffer, $\mathrm{pH} 10.0$ with $3 \mathrm{mM}$ benzamidine overnight at $4{ }^{\circ} \mathrm{C}$. The immobilized enzyme was prepared freshly for each hydrolysis experience.

The supernatant was separated from the particles by vacuum filtration. Samples were taken and the Bradford method was used for protein determination in the supernatant with Coomassie ${ }^{\circledR}$ Plus (Pierce, IL, USA). The amount of immobilized protein was considered to be the difference between the total incubated amount and the protein in the supernatant. Urea $6 \mathrm{M}$ was used to denaturate and remove unadsorbed/bond enzyme when covalent binding was involved. The carrier was then washed several times, first with the immobilization buffer and then with Tris/HC buffer without $\mathrm{CaCl}_{2}$. The washing procedure with Tris/HCl buffer was repeated four times.

\subsection{Measurement of trypsin activity}

Trypsin activity of immobilized and native enzyme preparations was monitored hydrolysing $\mathrm{N}$ - $\alpha$-benzoyl-DL-arginine-p-nitroanilide (BAPNA) in $0.05 \mathrm{M}$ Tris buffer with $0.02 \mathrm{M} \mathrm{CaCl}_{2}$ at $\mathrm{pH} 8.0$ [25].

Hydrolyses of $1 \mathrm{mM}$ BAPNA in Tris buffer (a dilution from a $25 \mathrm{mg} \mathrm{mL}^{-1}$ BAPNA solution in DMSO was freshly prepared) with immobilized enzyme were carried out at $25^{\circ} \mathrm{C}$ in a $50 \mathrm{~mL}$ stirred, tank-type, batch reactor equipped with temperature control. Samples of $1 \mathrm{~mL}$ were collected at different times and the reaction was stopped with $0.25 \mathrm{~mL}$ of acetic acid $30 \%(\mathrm{v} / \mathrm{v})$. The samples were vacuum filtered. The rate of p-nitroaniline formation was determined by measuring absorbance of supernatant at $410 \mathrm{~nm}$ in a microplate reader (Synergy HT, Bio-Tek, Winooski, VT, USA). The extinction coefficient used was $8.8 \mathrm{~L} \mathrm{mmol}^{-1} \mathrm{~cm}^{-1}$ [26].

Activity retention for the immobilized enzyme was determined by the ratio between the activity of the immobilized enzyme and the activity of a similar amount of the free enzyme.

\subsection{Storage stability and reusability}

Storage stability was determined incubating the immobilized enzyme in Trisbuffer with $0.020 \%(\mathrm{w} / \mathrm{v})$ sodium azide at $4{ }^{\circ} \mathrm{C}$ for 60 days. The remaining enzyme activity was determined with BAPNA as above and compared with the initial activity.

The reusability (or operational stability) of immobilized trypsin was studied by measuring the residual activity after five operational cycles and comparing it with the initial activity. Each time, immobilized trypsin was washed and centrifuged/filtered four times with Tris buffer.

\subsection{WPI hydrolysis}

Hydrolysis of whey protein isolate was carried out as described below with free and immobilized trypsin at different initial substrate concentration, temperature and $\mathrm{pH}$ values. Generally, solutions of WPI were prepared by suspending $2.5 \mathrm{~g}$ of WPI (except for the kinetics study where different substrate concentrations were used) in $50 \mathrm{~mL}$ of distilled water. The resulting solutions were then stirred for $1 \mathrm{~h}$ then heated to the hydrolysis temperature and adjusted to the desired $\mathrm{pH}$ with $\mathrm{NaOH}(1.0 \mathrm{M})$.

Enzymatic degradations were performed with free or immobilized trypsin in a $50 \mathrm{~mL}$ stirred, tank-type, batch reactor equipped with $\mathrm{pH}$ and temperature control. 
Table 1

Trypsin immobilization efficiency and activity retention.

\begin{tabular}{|c|c|c|c|c|}
\hline Immobilization method & $\begin{array}{l}\text { Immobilized } \\
\text { protein }(\%)\end{array}$ & Activity (U/g carrier) & $\begin{array}{l}\text { Specific activity } \\
\text { (U/mg protein) }\end{array}$ & Activity retention (\%) \\
\hline \multicolumn{5}{|l|}{ Crude trypsin } \\
\hline Adsorption at $\mathrm{pH} 8$ & $27.1 \pm 5.2$ & $5.01 \pm 0.56$ & $0.0428 \pm 0.010$ & $20.4 \pm 6.4$ \\
\hline Covalently attached to glyoxyl-spent grain & $66.4 \pm 4.2$ & $9.07 \pm 4.14$ & $0.026 \pm 0.010$ & $11.5 \pm 4.5$ \\
\hline $\begin{array}{l}\text { Covalently attached to glyoxyl-spent grain in } \\
\text { the presence of benzamidine }\end{array}$ & $68.7 \pm 1.0$ & $8.25 \pm 0.96$ & $0.024 \pm 0.001$ & $10.5 \pm 0.5$ \\
\hline $\begin{array}{l}\text { Covalently attached to amine-spent grain } \\
\text { with glutaraldehyde }\end{array}$ & $61.3 \pm 7.2$ & $5.60 \pm 0.05$ & $0.0196 \pm 0.002$ & $8.51 \pm 0.96$ \\
\hline $\begin{array}{l}\text { Covalently attached to amine-spent grain } \\
\text { with glutaraldehyde in the presence of } \\
\text { benzamidine }\end{array}$ & $53.4 \pm 2.7$ & $5.06 \pm 0.45$ & $0.0202 \pm 0.002$ & $8.80 \pm 0.67$ \\
\hline \multicolumn{5}{|l|}{ Purified trypsin } \\
\hline $\begin{array}{l}\text { Covalently attached to glyoxyl-spent grain in } \\
\text { the presence of benzamidine }\end{array}$ & $69.8 \pm 3.9$ & $44.3 \pm 2.2$ & $0.399 \pm 0.012$ & $46.0 \pm 2.3$ \\
\hline
\end{tabular}

The $\mathrm{pH}$ was kept constant at the desired value with $0.25 \mathrm{M}$ or $0.1 \mathrm{M} \mathrm{NaOH}$. The temperature was kept at constant values ranging from 37 to $60^{\circ} \mathrm{C}$, depending on the experiment.

The degree of hydrolysis ( $\mathrm{DH}$ ) achieved (ratio between the amount of peptide bounds cleaved and the total amount of peptide bounds) was measured by the $\mathrm{pH}$-stat method [27]. For each experiment, samples were collected at variable intervals of time, inactivated by decreasing the $\mathrm{pH}$ to 3.0, immediately frozen and stored at $-20^{\circ} \mathrm{C}$ until further analysis. All hydrolysis experiments were performed in triplicate.

\subsection{Quantification of the degree of protein hydrolysis}

Quantification of $\mathrm{DH}$ by the $\mathrm{pH}$ stat method was carried out by measuring the amount of $\mathrm{NaOH}$ used to keep the $\mathrm{pH}$ constant. The $\mathrm{DH}$ was calculated as described by Adler-Nissen [27]. The value used for the total number of peptide bonds in the protein substrate (whey protein isolate) was $8.8 \mathrm{meqv}_{\text {peptide bonds }} / \mathrm{g}_{\text {protein }}$. The average dissociation values $(p K)$ for the $\alpha$-amino groups of peptides and proteins used to calculate the degree of dissociation $(\alpha)$ for the $\alpha$-amino groups were the ones presented by Adler-Nissen [27].

\subsection{Peptide profile of hydrolysates}

The peptide profile of the hydrolysates and the native proteins degradation $(\alpha-$ La and $\beta$-Lg) were analysed by RP-HPLC. Prior to analysis, samples were diluted 20 times with ultra purified water. They were then injected in a reverse phase column C18 Symmetry 300 , Waters, USA ( $5 \mathrm{~mm}, 300 \AA, 250 \times 4.6 \mathrm{~mm}^{2}$ i.d.) installed on a liquid chromatograph (formed by an intelligent HPLC pump PU-2080 Plus, a ternary gradient unit LG-2080-02 and a 3-Line Degasser DG-2080-53, all from Jasco, Japan) to promote peptide separation according to their polarity. A symmetry guard column (Waters, USA) was used as pre-column. The elution flow rate was $0.75 \mathrm{~mL} \mathrm{~min}^{-1}$ with the following gradient of eluents (A: $0.1 \%$ trifluoroacetic acid - TFA - in water; B: $0.1 \%$ TFA in acetonitrile): $0-30 \mathrm{~min}, 100-50 \% \mathrm{~A} ; 30-35 \mathrm{~min}, 50-20 \% \mathrm{~A} ; 35-40 \mathrm{~min}$, $20 \%$ A. Under these conditions the retention time for $\alpha$-La was $30.3 \mathrm{~min}$ and for $\beta$-Lg was $32.2 \mathrm{~min}$. Monitoring was made at $215 \mathrm{~nm}$ and $35^{\circ} \mathrm{C}$ by a diode array detector LabChrom L-7455, Merck Hitachi, Japan.

Some samples were also analysed by RP-HPLC/ESI-MS. In this case, diluted samples were injected in a reverse phase column C18 Purospher Star from VWR, Germany $\left(5 \mu \mathrm{m}, 150 \times 4.6 \mathrm{~mm}^{2}\right.$ i.d.) installed on a liquid chromatograph (formed by a Surveyor LC Pump Plus, a LC Autosampler Plus and a Surveyor PDA plus detector, all from Finnigan, San Jose, USA). The elution flow rate was $0.5 \mathrm{~mL} \mathrm{~min}^{-1}$ with the following gradient of eluents (A: $0.1 \%$ TFA in water; B: $0.1 \%$ TFA in acetonitrile): $0-30 \mathrm{~min}, 100-50 \%$ A; $30-35 \mathrm{~min}, 50-20 \%$ A; 35-40 min, $20 \%$, followed by re-equilibration to the starting conditions. Monitoring was made at $220 \mathrm{~nm}$ at $30^{\circ} \mathrm{C}$.

The photo diode array detector's cell outlet was connected in series to the probe of the mass spectrometer. The mass spectrometer was a Finnigan LCQ Deca XP Max (Finnigan/Thermo Unicam, San Jose, USA), equipped with atmosphere pressure ionization (API) source, using ESI interface. The capillary voltage was $3 \mathrm{~V}$ and the capillary temperature was $190^{\circ} \mathrm{C}$. Spectra were recorded in positive ion mode for $\mathrm{m} / \mathrm{z}$ values ranging between 250 and 3000 . The mass spectrometer was programmed to perform a full mass scan.

\section{Results and discussion}

\subsection{Immobilization on spent grains}

Immobilization efficiency in carriers with chemical modification of the surface was better than with simple adsorption, as expected, with efficiencies around 60\% (Table 1 ). The best results concerning protein retention were obtained with glyoxyl spent grain (almost 70\%). The driving force for the immobilization with glyoxyl-carriers is the density of lysines in the enzyme (the reactive group). Trypsin may have rich lysine areas which could explain why this support has been successfully used. As the isoelectric point of trypsin is 10.5 [28], electrostatic repulsions are probably lower at the immobilization $\mathrm{pH}$ (10) making binding more efficient.

Although the amount of immobilized protein was higher when chemical bonds were involved, the specific activity was lower, indicating strong enzyme inactivation (Table 1). In fact, enzyme immobilized through adsorption showed the highest activity retention (20\%). The necessary conditions for covalent attachment of an enzyme to a carrier are such that some loss of activity is inevitable. Besides, the active sites may not be as accessible to the substrate by partial obstruction or their conformation may be altered. Also some autolysis is likely to occur, especially in the cases where immobilization was done at $\mathrm{pH} 8$ (the optimum pH for the enzyme).

It has also been referred that the presence of an enzyme inhibitor during the immobilization process can reduce enzyme inactivation. Benzamidine, a competitive inhibitor of trypsin, has been used during trypsin immobilization and it strongly adsorbs on the active site of the enzyme, greatly reducing the inactivation of trypsin ([29], e.g.). However, in this work, no significant differences were perceptible within the range of experimental conditions tested.

In order to be economically interesting, this kind of systems must be re-usable. Thus, operational stability was tested. The activity loss was high (above 50\%) when the enzyme was immobilized by adsorption. As only (weak) physical bonds being involved, probably considerable enzyme leaching took place during washings and operation resulting in high losses (Fig. 1). Operational stability of immobilized enzyme with glyoxyl and amine spent grains was much higher and even close to $100 \%$.

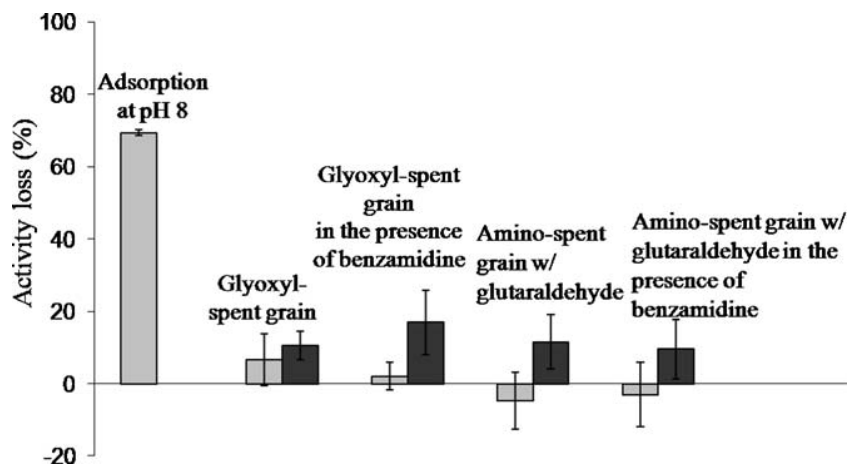

Fig. 1. Operational stability after four cycles and storage stability after 60 days in Tris/ $\mathrm{HCl}$ buffer at $4{ }^{\circ} \mathrm{C}$; $(\square)$ operational stability; ( $)$ storage stability. 

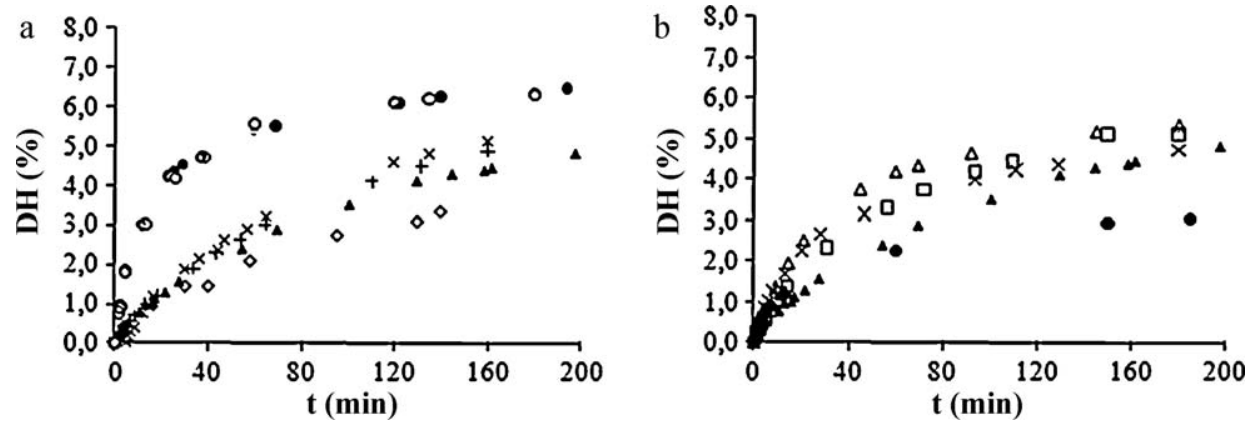

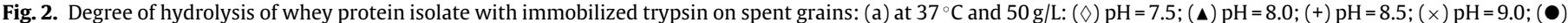
$(\bigcirc)$ and $(\bigcirc)$ free enzyme at pH 8.0; (b) pH 8 and $50 \mathrm{~g} / \mathrm{L}:(\Delta) 37^{\circ} \mathrm{C} ;(\square) 45^{\circ} \mathrm{C} ;(\triangle) 50^{\circ} \mathrm{C} ;(\times) 55^{\circ} \mathrm{C} ;(\bullet) 60^{\circ} \mathrm{C}$.

Carriers with glyoxyl and amine are also stable during storage and they retained more than $85 \%$ of the initial activity during 60 days at $4{ }^{\circ} \mathrm{C}$ (Fig. 1 ).

Free enzyme stability tests during 40 days led to a $40 \%$ decrease in the activity when the enzyme was stored in $0.05 \mathrm{M}$ Tris $/ \mathrm{HCl}$ buffer at $\mathrm{pH} 8$ and in the presence of $\mathrm{CaCl}_{2}$ (so with reduced autolysis), and to a $90 \%$ decrease when the enzyme was stored in Tris/HCl buffer at $\mathrm{pH} 8$ or phosphate buffer at $\mathrm{pH} 7$. As the storage stability and operational stability losses are most of the times significantly less than $40 \%$ (Fig. 1) the enzyme was effectively immobilized and stabilized and these losses cannot be attributed only to the presence of $\mathrm{CaCl}_{2}$ that inhibits the autodigestion of trypsin. The retention of activity after urea $6 \mathrm{M}$ used to wash the immobilized protein also leads to the same conclusion.

Sometimes (Fig. 1) the retained activity of the carrier increased with repeated reaction cycles or with storage. Although the immobilized enzymes were washed with urea once and with immobilization buffer four times, this may indicate that some noncovalent coupled proteins were still present and did not allow the binding of the substrate to the inner trypsin molecules. On the other hand, as some outer molecules may be physically adsorbed they are more easily inactivated due to conformational changes and denaturation, and their activity may become lower than the activity of the inner molecules [30].

Generally the recovered activity after the immobilization procedure was low. However, in these preliminary tests, the enzyme used was not very purified and this often causes low retention of activity ([31], e.g.). Thus, a more purified enzyme (a bovine trypsin with a BAEE activity of 11,000 BAEE U/g and chymotryptic activity $\leq 0.2 \%$ ) was used in whey protein hydrolysis both to improve activity retention and to avoid the interference of chymotrypsin. The immobilization activity retention towards BAPNA was four times higher in this case while the relative amount of immobilized protein was very similar (Table 1 ).

\subsection{Degree of hydrolysis with immobilized trypsin and activity retention}

When the macrosubstrate (WPI) was used, the activity of the immobilized enzyme was only $17.6 \pm 0.3 \%$ of the free enzyme activity (measured at $\mathrm{pH} 8$ and $37^{\circ} \mathrm{C}$ ). Activity with WPI was determined as the number of peptide bonds broken per min during the first $3 \mathrm{~min}$ of hydrolysis. As the whey proteins are much bigger molecules than BAPNA the binding to the active sites of the enzyme might be more difficult either by diffusional limitations or by partial spatial obstruction of the active site. In fact, from the analysis of Fig. 2 it can be observed that for the free enzyme the initial rate of hydrolysis is high, suggesting that the reaction is the rate-limiting step. At higher values of the degree of hydrolysis, the reaction rate strongly decreases. In the case of immobilized trypsin on spent grains, the initial rate of hydrolysis is much smaller indicating possible substrate diffusional limitations. As the hydrolysis products are smaller than the substrates, product accumulation due to diffusional limitations is not so likely to occur, which is confirmed by the fact that the difference between the rate of hydrolysis of free and immobilized enzymes decreases with the time of hydrolysis (after $20 \mathrm{~min}$, the immobilized enzyme overall activity is already $27 \%$ of that of the free enzyme).

The reduced activity of immobilized proteases towards high molecular weight substrates has been referred in literature. For instance, Arasaratnam et al. [30] refer that the proximity of a large internal support surface, where the enzyme is usually immobilized, may promote poor performance of immobilized proteins on macromolecular substrates. They achieved activity retentions lower than $10 \%$ towards azocasein. Jarzebski et al. [32] immobilized trypsin in siliceous mesostructured cellular foams functionalised with different organosilanes and achieved retained activities between 4.2 and $23.9 \%$ towards casein, considering 5 min of hydrolysis time at $\mathrm{pH}$ 7.8 and $37^{\circ} \mathrm{C}$.

The degree of hydrolysis of the WPI with trypsin immobilized on spent grains was $4.8 \%$ after $3 \mathrm{~h}$, against $6.5 \%$ with the free enzyme. The enzyme immobilized on spent grains had lower activity and thus it is expected that the degree of hydrolysis achieved is lower for the same time of hydrolysis. However, the specificity of the enzyme limits the final degree of hydrolysis and it would probably be higher and closer to the value obtained with the free enzyme if a longer time had been used.

The optimum $\mathrm{pH}$ for the hydrolysis of WPI with trypsin immobilized on glyoxyl-spent grains seems to be 9 (Fig. 2a), slightly higher than for the free enzyme (8.5). However, the DH profiles are very similar for $\mathrm{pH} \mathrm{8,8.5}$ and 9 suggesting an optimal $\mathrm{pH}$ interval. The same behaviour was already observed for the free enzyme but for $\mathrm{pH}$ values ranging from 8.5 to 9.5 .

Fig. $2 \mathrm{~b}$ shows the degree of hydrolysis determined by the $\mathrm{pH}$-stat method for WPI hydrolysed at several temperatures with trypsin immobilized on spent grains. The activity of the enzyme increased with temperature and a maximum interval was found at $45-50{ }^{\circ} \mathrm{C}$ for a hydrolysis time of $3 \mathrm{~h}$, slightly higher than the maximum found with for free trypsin: $45^{\circ} \mathrm{C}$ (result not shown). The immobilized enzyme is thus slightly more stable at higher temperatures than the free enzyme. As a result, the enzyme still retains some activity after $70 \mathrm{~min}$ at $60^{\circ} \mathrm{C}$ while with the free enzyme after $10 \mathrm{~min}$ at that temperature almost no activity was observed. The final degree of hydrolysis achieved at $60^{\circ} \mathrm{C}$ for the free enzyme was $1.1 \%$ after $10 \mathrm{~min}$ (and this value remained constant for the following hour) while with the immobilized enzyme it was $2.3 \%$ after $1 \mathrm{~h}$ and $3.0 \%$ after $3 \mathrm{~h}$. Furthermore, and although the initial activity of the immobilized protein is ca. five times smaller than the initial activity of the free enzyme, the degree of hydrolysis achieved after $2 \mathrm{~h}$ at $55^{\circ} \mathrm{C}$ crosses over and starts to be higher in the case of the immobi- 
Table 2

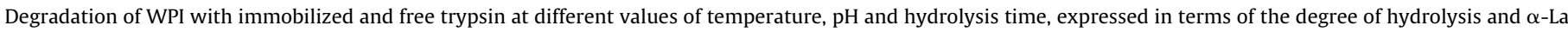
and $\beta$-Lg degradation.

\begin{tabular}{|c|c|c|c|c|c|c|}
\hline Enzyme & $\mathrm{pH}$ & $T\left({ }^{\circ} \mathrm{C}\right)$ & $\begin{array}{l}\text { Hydrolysis } \\
\text { time (min) }\end{array}$ & DH (\%) & $\begin{array}{l}\alpha \text {-La concentration (\% of } \\
\text { initial } \alpha \text {-La concentration) }\end{array}$ & $\begin{array}{l}\beta-\operatorname{Lg} \text { concentration (\% of } \\
\text { initial } \beta \text { - } \mathrm{Lg} \text { concentration) }\end{array}$ \\
\hline Immobilized & 8 & 37 & 22 & $1.1 \pm 0.0$ & $24.5 \pm 1.1$ & $72.9 \pm 3.8$ \\
\hline Immobilized & 8 & 37 & 160 & $4.4 \pm 0.1$ & $16.9 \pm 0.3$ & $18.3 \pm 0.6$ \\
\hline Immobilized & 8 & 37 & 500 & $6.5 \pm 0.0$ & $4.7 \pm 0.1$ & $14.6 \pm 0.7$ \\
\hline Immobilized & 7.5 & 37 & 140 & $3.3 \pm 0.0$ & $36.6 \pm 2.4$ & $58.8 \pm 3.0$ \\
\hline Immobilized & 8.5 & 37 & 110 & $4.1 \pm 0.1$ & $17.1 \pm 0.5$ & $20.7 \pm 0.4$ \\
\hline Immobilized & 9.0 & 37 & 65 & $3.6 \pm 0.0$ & $10.1 \pm 0.4$ & $17.7 \pm 0.8$ \\
\hline Immobilized & 8 & 45 & 110 & $4.4 \pm 0.1$ & $2.8 \pm 0.3$ & $12.2 \pm 0.5$ \\
\hline Immobilized & 8 & 50 & 70 & $4.4 \pm 0.1$ & Residual & $6.9 \pm 0.3$ \\
\hline Immobilized & 8 & 55 & 110 & $4.2 \pm 0.1$ & Residual & $3.8 \pm 0.3$ \\
\hline Immobilized & 8 & 60 & 185 & $3.0 \pm 0.4$ & - & - \\
\hline Free & 8 & 37 & 25 & $4.3 \pm 0.1$ & $2.9 \pm 0.1$ & $14.3 \pm 0.5$ \\
\hline Free & 8 & 37 & 240 & $6.3 \pm 0.0$ & $0.0 \pm 0.0$ & $0.9 \pm 0.2$ \\
\hline Free & 8 & 45 & 16 & $4.3 \pm 0.0$ & Residual & $7.6 \pm 0.2$ \\
\hline Free & 8 & 50 & 12 & $4.0 \pm 0.0$ & Residual & $5.0 \pm 0.3$ \\
\hline Free & 8 & 55 & 120 & $4.2 \pm 0.4$ & Residual & $1.8 \pm 0.4$ \\
\hline
\end{tabular}

Residual corresponds to the presence of a very small detectable peak, but with not enough resolution to be quantified ( $<0.8 \%)$.

lized enzyme (4.3\% against $4.2 \%$ ). Thus, the immobilized enzyme can be used in a broader interval of temperatures and therefore may be useful if, for some operational reason, the hydrolysis has to be performed at higher temperatures. It has also shown to be more adequate in reactions that need longer times of hydrolysis at moderate temperatures. In all cases, at $70^{\circ} \mathrm{C}$, inactivation of the enzyme occurred rapidly and the hydrolysis reaction stopped in less than 2 min (results not shown).

For the sake of clarity, only replicates of the experiment with the free enzyme were presented. However, the experimental error for the other experiments is presented with the DH values in Table 2.

The operational stability was also tested. The carrier was used five times during $30 \mathrm{~min}$ in $50 \mathrm{~g} / \mathrm{LWPI}$ at $\mathrm{pH} 8$ and $37^{\circ} \mathrm{C}$ with activity retention of $94 \pm 5 \%$.

\subsection{Peptide profile and composition of the hydrolysates}

The RP-HPLC profiles of the WPI hydrolysates with trypsin immobilized on glyoxyl-spent grains at $\mathrm{pH} 8$ are shown in Fig. 3. The peaks with an average retention time of 30.3 and $32.2 \mathrm{~min}$ correspond to $\alpha$-La and $\beta$-Lg, respectively.

When the effect of the temperature on the peptide profile is analysed, the main differences appear in the native $\alpha$-La and $\beta$ Lg (Fig. 3). With the increase of the hydrolysis temperature the amount of native proteins still present at a DH close to $4 \%$ decreases. This decrease is higher for $\alpha$-La, which is understandable because this protein is more heat sensitive than $\beta$-Lg. Differences in the amount of the native protein present apart, at temperatures equal to or below $50^{\circ} \mathrm{C}$ the peptide profiles correspondent to a degree of hydrolysis of $4.2-4.4 \%$ are quite similar. Similarly to the hydrolysate from the free enzyme, a wide peak in the hydrophobic region appears also in the present case for temperatures above $60^{\circ} \mathrm{C}$, probably corresponding to $\beta$ - $\mathrm{Lg}$ denaturation.

RP-HPLC peptide pattern seems to be the same for $\mathrm{pH}$ values between 8 and 9 and will not be presented. However, at pH 7.5 both $\alpha$-La and $\beta$-Lg seem to be more resistant to the hydrolysis (Table 2 ) and smaller peptides are preferred by the enzyme than the intact protein. A change in the conformation of the native proteins (due to changing $\mathrm{pH}$ values) may be making the substrate binding to the active site even more difficult. Huang et al. [8] also obtained high intact $\alpha$-La and $\beta$-Lg concentrations when hydrolysing WPI at $\mathrm{pH}$ 7.6 and $24^{\circ} \mathrm{C}$ for $90 \mathrm{~min}$ (15.8 and $43.5 \%$, respectively) while Chen et al. [3] achieved $65 \%$ of intact $\beta$ - $\mathrm{Lg}$ at $\mathrm{pH} 8$, after $20 \mathrm{~min}$.

The peptides formed with the free and the immobilized enzyme are essentially the same (Fig. 4) and the mechanism of peptide formation seems also to be the same with major whey protein peaks decreasing to give rise to smaller peaks, some of which appear right from the beginning and keep growing while others, more hydrophobic and, thus, probably bigger, further degraded into the smaller peptides. As the peaks from the RP-HPLC are many and

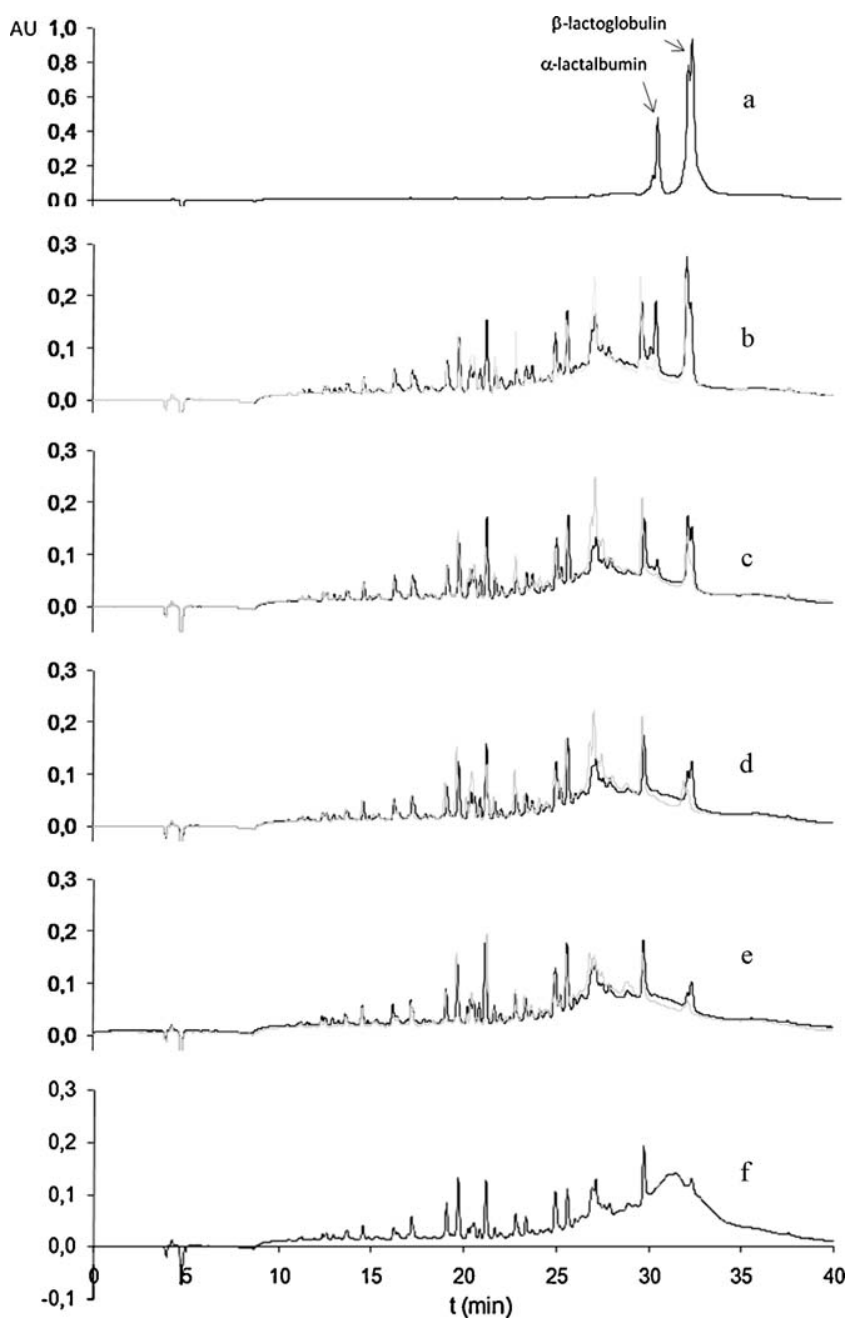

Fig. 3. RP-HPLC profile of whey protein hydrolysates from free (grey) and immobilized (black) trypsin on spent grains at $\mathrm{pH} 8.0$ and $50 \mathrm{~g} / \mathrm{L}$ of WPI: (a) $\mathrm{DH}=0 \%$; (b) $37^{\circ} \mathrm{C}$ $(t=159 \mathrm{~min} ; \mathrm{DH}=4.4 \%) ;(\mathrm{c}) 45^{\circ} \mathrm{C}(t=110 \mathrm{~min} ; \mathrm{DH}=4.4 \%) ;(d) 50^{\circ} \mathrm{C}(t=69.5 \mathrm{~min}$; $\mathrm{DH}=4.4 \%)$; (e) $55^{\circ} \mathrm{C}(t=111 \mathrm{~min} ; \mathrm{DH}=4.2 \%)$; (f) $60^{\circ} \mathrm{C}(t=185 \mathrm{~min} ; \mathrm{DH}=3.0 \%)$. 

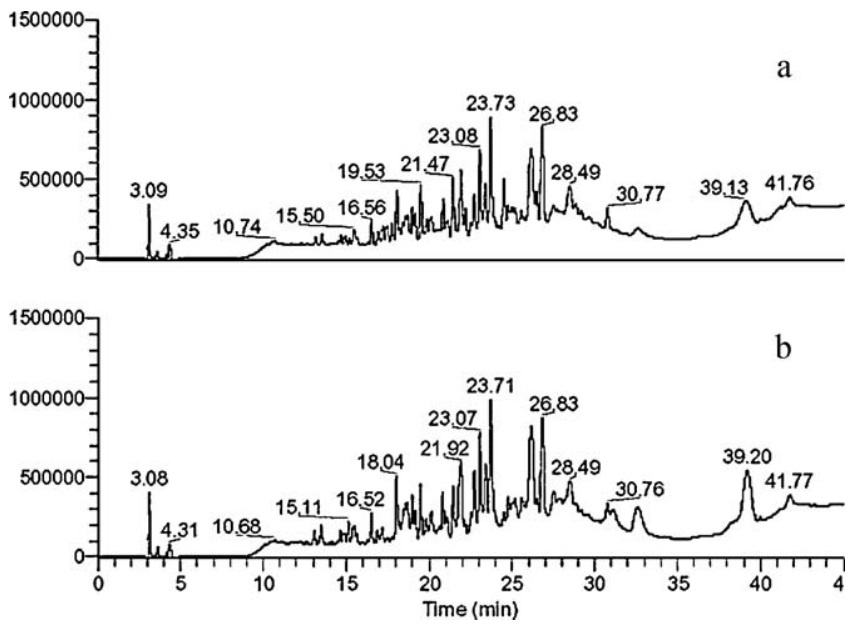

Fig. 4. Hydrolysates' peptide profile from the RP-HPLC/MS analysis: (a) free enzyme $(\mathrm{DH}=6.3 \%)$; (b) enzyme immobilized on spent grains ( $\mathrm{DH}=6.5 \%)$.

too close to each other, MS analysis allowed confirming that the peaks with the same retention time have the same mass and thus are probably referring to the same peptide. However there are small differences in the chromatograms particularly in the more hydrophobic regions, mainly corresponding to intact proteins that can arise from the small difference in the final hydrolysis degree of the two samples or from the difference in selectivity of the immobilized enzyme towards larger substrates. Also the relative amount of some smaller peptides seems to be different.

Another interesting feature is that small peaks appear in the chromatogram of the hydrolysate obtained with the free enzyme (see Fig. 4a), e.g., in the region from 16 to $18 \mathrm{~min}$ and near $25 \mathrm{~min}$. These peaks are not present in Fig. 4b, which may indicate that they are originating from trypsin autolysis.

Although general peptide profiles of both free and immobilized enzyme are similar, the small differences detected in Figs. 3 and 4 become evident with the analysis of Table 2 . In fact, native proteins are less degraded by proteolysis with immobilized enzyme in all cases, confirming size (steric) limitation problems. These differences do not exist for the hydrolysis of $\alpha$-La above $50^{\circ} \mathrm{C}$, inclusive. Although the final degree of hydrolysis is essentially the same ( $6.5 \%$ for the immobilized enzyme and $6.3 \%$ for the free enzyme), there seems to be a preferential breakdown of peptides instead of big intact proteins. Different peptide patterns of the hydrolysates obtained with free and immobilized proteins have been described (e.g., [12]). $\beta$ - $\mathrm{Lg}$ for instance has $29-40 \AA$ [17] and, although the enzyme is not immobilized on pores (because either they do not exist or they are too small), this can cause problems if the enzyme is for instance too close to the carrier and if the active site is not completely turned to the outer side of the carrier (so that the substrate can come close and rotate freely in order to fit the active site).

\subsection{Kinetics of immobilized trypsin}

The kinetics of free enzyme and enzyme immobilized on spent grains was evaluated at $37^{\circ} \mathrm{C}$ and $\mathrm{pH}$ 8. Seven WPI concentrations were used: $5,10,15,25,35,50$ and $75 \mathrm{~g} / \mathrm{L}$. A simple Michaelis-Menten model was considered for the kinetic analysis. The concentration of all cleavable sites was used as the substrate concentration. The resulting correlation coefficient was 0.99 for the free enzyme and 0.98 for the immobilized enzyme. The kinetic analysis showed that the apparent $K_{\mathrm{m}}$ for the immobilized trypsin was about 6 times higher than that found for the soluble enzyme (86.1 eq $\mathrm{elig}_{\text {lig }} / \mathrm{L}$ against $13.6 \mathrm{eq}_{\text {lig }} / \mathrm{L}$, respectively). This may again indi- cate that there are diffusional limitations due to immobilization. The $v_{\max }$ of the immobilized enzyme $\left(6.41 \times 10^{-3} \mathrm{~min}^{-1}\right)$ is around $13 \%$ of the $v_{\max }$ from the free enzyme $\left(4.89 \times 10^{-2} \mathrm{~min}^{-1}\right)$ as expected from the results above. There may be substantial multilayers of trypsin on the flat surface area of spent grains, and the internal layers of enzyme are less accessible for the substrate molecules, specially the larger ones, and therefore, a significant amount of trypsin may not be readily available to the substrate (together with the possible steric hindrance effects referred above).

Changes in the kinetic constants due to diffusional limitations are common in literature. For instance, Duggal and Buchholz [11] studied the effects of immobilization of trypsin on its intrinsic kinetics. They concluded that there are significant shifts in association constants for substrates and inhibitors due to covalent binding onto a rigid support. $K_{\mathrm{M}}$ and $K_{\mathrm{I}}$ values were changed by factors up to 6 and relative affinities were also different as compared to the native enzyme. Similar findings were obtained for the maximal reaction rates.

\section{Conclusions}

Although the amount of immobilized protein was high, activity recovery was initially low with all the tested carriers. However, when a more purified enzyme from bovine pancreas was used with glyoxyl-spent grain the activity retention was of $46 \%$ (against $11 \%$ with crude enzyme). Thus it can be stated that trypsin was successfully immobilized. Spent grains can be used with multipoint covalent attachment using glycidol. Trypsin immobilized on spent grains showed significant activity towards whey proteins. The immobilized enzyme is slightly more stable at temperatures between $50^{\circ} \mathrm{C}$ and $60^{\circ} \mathrm{C}$ allowing its use at a broader range of temperatures.

The peptides present in the WPI hydrolysates from free enzyme and enzyme immobilized on spent grains were the same, which indicates that spent grains can be used as carriers for trypsin to produce hydrolysates with peptides similar to those obtained with the free enzyme (thus with similar bioactivity).

\section{References}

[1] de Wit JN. Nutritional and functional characteristics of whey proteins in food products. J Dairy Sci 1998;81:597-608.

[2] Turgeon SL, Beaulieu M. Improvement and modification of whey protein gel texture using polysaccharides. Food Hydrocolloid 2001;15:583-91.

[3] Chen SX, Swaisgood HE, Foegeding EA. Gelation of $\beta$-lactoglobulin treated with limited proteolysis by immobilized trypsin. J Agric Food Chem 1994;42:234-9.

[4] Otte J, Zakora M, Qvist KB, Olsen CE, Barkholt V. Hydrolysis of bovine $\beta$ lactoglobulin by various proteases and identification of selected peptides. Int Dairy J 1997; 7:835-48.

[5] Pihlanto-Leppälä A, Rokka I, Korhonen H. Angiotensin I converting enzyme inhibitory peptides derived from bovine milk proteins. Int Dairy 1998:8:325-31.

[6] Gauthier SF, Paquin P, Pouliot Y, Turgeon S. Surface-activity and related functional-properties of peptides obtained from whey proteins. J Dairy Sci 1993;76(1):321-8.

[7] Singh AM, Dalgleish DG. The emulsifying properties of hydrolyzates of whey proteins. J Dairy Sci 1998;81(4):918-24.

[8] Huang XL, Catignani GL, Swaisgood HE. Modification of rheological properties of whey protein isolates by limited proteolysis. Nahrung-Food 1999;43(2):79-85.

[9] Davis JP, Doucet D, Foegeding EA. Foaming and interfacial properties of hydrolyzed beta-lactoglobulin. J Colloid Interf Sci 2005;288(2):412-22.

[10] Amaral IPG, Carneiro-da-Cunha MG, Carvalho LB, Bezerra RS. Fish trypsin immobilized on ferromagnetic Dacron. Process Biochem 2006;41(5):1213-6.

[11] Duggal SK, Buchholz K. Effects of immobilization on intrinsic kinetics and selectivity of trypsin. Eur J Appl Microbiol Biotechnol 1982;16(2-3):81-7.

[12] Lorenzen PC, Schlimme E. Characterization of trypsin immobilized on oxiraneacrylic beads for obtaining phosphopeptides from casein. Z Ernahrungswiss 1995;34(2):118-30.

[13] Park O, Swaisgood HE, Allen JC. Calcium binding of phosphopeptides derived from hydrolysis of alpha(s)-casein or beta-casein using immobilized trypsin. J Dairy Sci 1998;81(11):2850-7.

[14] Krogh TN, Berg T, Hojrup P. Protein analysis using enzymes immobilized to paramagnetic beads. Anal Biochem 1999;274(2):153-62. 
[15] Pedroche J, Yust MM, Lqari H, Girón-Calle J, Vioque J, Alaiz M, et al. Production and characterization of casein hydrolysates with a high amino acid Fisher's ratio using immobilized proteases. Int Dairy J 2004;14:527-33.

[16] Bai H, Ge SJ, Zhang LX. Total hydrolysis of food proteins by the combined use of soluble and immobilized protease. Int J Food Sci Technol 1999;34(1):95-9.

[17] Yiu HHP, Botting CH, Botting NP, Wright PA. Size selective protein adsorption on thiol-functionalised SBA-15 mesoporous molecular sieve. Phys Chem Chem Phys 2001;3(15):2983-5.

[18] Mussatto SI, Dragone G, Roberto IC. Brewers' spent grain: generation, characteristics and potential applications. J Cereal Sci 2006;43:1-14.

[19] Celus I, Brijs K, Delcour JA. Enzymatic hydrolysis of Brewers' spent grain proteins and technofunctional properties of the resulting hydrolysates. J Agric Food Chem 2007;55:8703-10.

[20] Brányik T, Vicente AA, Machado Cruz JM, Teixeira JA. Spent grains - a new support for brewing yeast immobilisation. Biotechnol Lett 2001;23:1073-8.

[21] Lopez-Gallego F, Betancor L, Hidalgo A, lamora-Ortiz G, Mateo C, FernandezLafuente R, et al. Stabilization of different alcohol oxidases via immobilization and post immobilization techniques. Enzyme Microb Technol 2007;40(2):278-84.

[22] Mateo U, Palomo JM, Fuentes M, Betancor L, Grazu V, Lopez-Gallego F, et al. Glyoxyl agarose: a fully inert and hydrophilic support for immobilization and high stabilization of proteins. Enzyme Microb Technol 2006;39(2): 274-80.

[23] Pedroche J, Yusta MM, Mateo C, Fernández-Lafuente R, Girón-Calle J, Alaiz M, et al. Effect of the support and experimental conditions in the intensity of the multipoint covalent attachment of proteins on glyoxyl-agarose supports: correlation between enzyme-support linkages and thermal stability. Enzyme Microb Technol 2007;40(5):1160-6.

[24] Guisan JM. Aldehyde-agarose gels as activated supports for immobilizationstabilization of enzymes. Enzyme Microb Technol 1988;10(6):375-82.

[25] Erlanger BF, Cohen W, Kokowsky N. Preparation and properties of 2 new chromogenic substrates of trypsin. Arch Biochem Biophys 1961;95(2):271.

[26] Huckel M, Wirth H-J, Eran M. Porous zirconia: a new support material for enzyme immobilization. J Biochem Biophys Methods 1996;31:165-79.

[27] Adler-Nissen J. Enzymic hydrolysis of food proteins. London, U.K.: Elsevier Applied Science Publishers; 1986.

[28] Diaz JF, Balkus KJ. Enzyme immobilization in MCM-41 molecular sieve. J Mol Catal B: Enzym 1996;2(2-3):115-26.

[29] Blanco RM, Calvete JJ, Guisan JM. Immobilization-stabilization of enzymes variables that control the intensity of the trypsin (amine) agarose (aldehyde) multipoint attachment. Enzyme Microb Technol 1989;11(6):353-9.

[30] Arasaratnam V, Galaev IY, Mattiasson B. Reversibly soluble biocatalyst: optimization of trypsin coupling to Eudragit S-100 and biocatalyst activity in soluble and precipitated forms. Enzyme Microb Technol 2000;27(3-5):254-63.

[31] Goradia D, Cooney J, Hodnett BK, Magner E. The adsorption characteristics, activity and stability of trypsin onto mesoporous silicates. J Mol Catal B: Enzym 2005;32(5-6):231-9.

[32] Jarzebski AB, Szymanska K, Bryjak J, Mrowiec-Białon J. Covalent immobilization of trypsin on to siliceous mesostructured cellular foams to obtain effective biocatalysts. Catal Today 2007;124(1-2):2-10. 